\title{
APAKAH KONVERGENSI IFRS MEMPERBAIKI KARAKTERISTIK LABA BERSIH?
}

\section{DOES IFRS ENHANCES NET INCOME'S CHARACTERISTICS?}

\author{
Yuna Adhi Pamungkas ${ }^{1}$, Caecilia Dita Purwanti ${ }^{2}$, Ari Budi Kristanto ${ }^{3}$ \\ ${ }^{123}$ Fakultas Ekonomika dan Bisnis, Universitas Kristen Satya Wacana \\ 232015026@student.uksw.edu1,232015006@student.uksw.edu², ari.kristanto@ staff.uksw.edu ${ }^{3}$
}

\begin{abstract}
Abstrak
Penelitian ini bertujuan untuk mengetahui apakah karakteristik kualitas laba bersih menjadi semakin baik setelah konvergensi IFRS. Tujuan penelitian ini dijawab dengan cara membandingkan persistensi, kemampuan prediksi, variabilitas dan relevansi nilai dari laba bersih sebelum dan sesudah implementasi IFRS. Populasi dalam penelitian ini adalah seluruh perusahaan yang terdaftar dalam Bursa Efek Indonesia (BEI) tahun 2005 sampai 2016. Sampel dalam penelitian ini diperoleh dengan metode purposive sampling dengan kriteria (1)perusahaan nonkeuangan; (2) terdaftar berturut-turut selama tahun 2005-2016; (3) memiliki data penelitian yang lengkap. Sampel yang digunakan dalam penelitian ini berjumlah 150 perusahaan yang terdaftar dalam Bursa Efek Indonesia tahun 2005 sampai 2016. Hasil penelitian menunjukan bahwa variabilitas laba bersih setelah IFRS lebih rendah dari pada sebelum IFRS, sedangkan kemampuan memprediksi dan relevansi nilai laba bersih setelah IFRS lebih tinggi dibandingkan sebelum IFRS. Persistensi laba bersih setelah IFRS lebih rendah dibandingkan dengan sebelum IFRS. Hal ini membuktikan bahwa implementasi IFRS di Indonesia membawa manfaat bagi karakteristik, variabilitas, kemampuan prediksi dan relevansi nilai laba bersih, akan tetapi IFRS belum tentu dapat meningkatkan daya prediksi laba yang akan datang. Dari hasil penelitian ini, pengguna laporan keuangan diharapkan akan lebih yakin dalam menggunakan informasi laba bersih sebagai salah satu indikator dalam membuat keputusan ekonomi.
\end{abstract}

Kata Kunci: IFRS, kemampuan prediksi, laba bersih, persistensi, relevansi nilai, variabilitas

\begin{abstract}
This study aims to determine whether the quality characteristics of net income became better after IFRS convergence. The purpose of this study was answered by comparing persistence, predictive ability, variability and value relevance of net income before and after IFRS implementation. The population in this study are all companies listed in Indonesia Stock Exchange (BEI) in 2005 until 2016. The sample in this study obtained by purposive sampling method using following criterias (1) non-financial companies; (2) listed during 2005-2016; (3) provided with complete research data. The sample used in this study amounted to 150 companies listed in the Indonesia Stock Exchange 2005 to 2016. The results showed that the net profit variability after IFRS was lower than before IFRS, while the predictive ability and value relevance of net income after IFRS was higher than before IFRS. Persistence of net income after IFRS is lower than before IFRS. These prove that IFRS implementation in Indonesia brings benefits to the characteristics, variability, predictive ability and relevance of net income, but IFRS may not necessarily improve the predictive ability of earnings. From the results of this study, users of financial statements are expected to be more confident in using information net income as one indicator in making economic decisions.
\end{abstract}

Keywords: IFRS, predictive ability, net income, persistence, value relevance, variability. 


\section{PENDAHULUAN}

International Financial Reporting Standard (IFRS) adalah sebuah standar yang dipakai menjadi panduan dalam pelaporan keuangan yang digunakan secara global (Pacter, 2017). Standar pelaporan yang diinisiasi sejak tahun 2001 ini mulai diterapkan di Indonesia pada tahun 2008, sebagai konsekuensi dari komitmen Indonesia dalam forum negara-negara G20 (Nurharyanto, 2010). Penggunaan standar internasional dalam pelaporan keuangan di Indonesia dilakukan dengan konvergensi IFRS ke dalam PSAK, yaitu penyesuaian prinsip-prinsip dalam standar akuntansi keuangan yang mengacu pada IFRS untuk meningkatkan fungsi dan kualitas laporan keuangan. Implementasi IFRS di Indonesia diharapkan dapat membuat informasi dalam laporan keuangan lebih berkualitas, sehingga arus modal diharapkan dapat lebih lancar. Kelancaran arus modal bagi perusahaan diharapkan dapat menjadi basis penguatan daya saing perekonomian usaha secara mikro maupun makro.

Konvergensi IFRS di Indonesia dilaksanakan dengan gradual strategy (Suyatmini $\&$ Sheilla, 2014). Penerapan secara bertahap ini biasa digunakan pada negara-negara yang sedang berkembang seperti Indonesia, sehingga memberikan kesempatan penyesuaian dalam mengantisipasi perubahan. Nurharyanto (2010) menyatakan bahwa penerapan IFRS dicapai Indonesia dalam tiga tahap yaitu tahap adopsi (2008-2010), tahap persiapan akhir (2011) dan tahap implementasi (2012)

Fokus utama implementasi IFRS adalah pada meningkatnya kualitas dari Standar Akuntansi Keuangan (SAK), kualitas informasi keuangan dan komparabilitas dari laporan keuangan (Suyatmini \& Sheilla, 2014). Kualitas informasi dari laporan keuangan yang tinggi merupakan hal penting dari kerangka konseptual pelaporan keuangan yang menjadi dasar pengembangan standar akuntansi, termasuk IFRS. Karakteristik kualitatif yang dikemukakan dalam kerangkan konseptual IFRS dibagi kedalam fundamental characteristic dan enchanching characteristic (Mirza \& Holt, 2008). Dalam fundamental characteristic laporan keuangan memiliki karakteristik relevan dan reliabilitas. Adapun dalam enchanching characteristic, laporan keuangan diharapkan memiliki krakteristik dapat dibandingkan, tepat waktu, dapat dipahami dan dapat diverifikasi.

Konvergensi IFRS diharapkan membuat komparabilitas dari laporan keuangan menjadi meningkat. Komparabilitas mengacu pada informasi yang dapat dibandingkan antar waktu maupun antar entitas (Mirza \& Holt, 2008). Komparabilitas laporan keuangan dibutuhkan bagi pihak internal maupun eksternal perusahaan. Laporan keuangan yang memiliki komparabilitas memudahkan pihak internal untuk membandingkan kinerja perusahaan dari tiap periode. Bagi pihak eksternal komparabilitas laporan keuangan juga penting, karena komparabilitas yang baik dapat memudahkan pihak eksternal untuk membuat keputusan, antara lain keputusan investasi oleh investor.

Salah satu informasi penting dan potensial yang disajikan melalui pelaporan keuangan adalah laba (Kristanto, Tarigan, \& Tarigan, 2014). Menurut Paradiba and Nainggolan (2015), laba bersih merupakan salah satu tolok ukur kinerja keuangan yang diperhatikan oleh investor yang hendak menanamkan dananya dalam saham untuk tujuan investasi. Selain untuk mengevaluasi kinerja dalam suatu periode, analisis laba juga dapat membantu membandingkan kinerja perusahaan antar waktu, maupun dengan perusahaan lainnya. Berdasar pada pentingnya informasi laba, maka kualitas informasi laba perlu diupayakan untuk menjamin kebermanfaatan laporan keuangan. Dechow and Schrand (2004) menyatakan bahwa laba akan memiliki kualitas yang tinggi jika laba tersebut lebih persisten dan stabil, memiliki hubungan yang lebih kuat dengan arus kas masa depan, dan memiliki hubungan yang kuat dengan performa harga saham saat ini atau nilai pasar. Diperkuat oleh Kabir and Laswad (2011), laba yang berkualitas memiliki karakteristik 
relevan, kemampuan prediksi, persisten, dan memiliki variabilitas yang rendah. Relevansi nilai merupakan tolok ukur informasi yang terdapat dalam laporan keuangan untuk mengetahui nilai perusahaan (Kargin, 2013). Informasi akuntansi memiliki nilai prediktabilitas ketika informasi dapat membantu pengguna laporan keuangan untuk memprediksi kejadian di masa yang akan datang berdasarkan masa lalu dan kejadian saat ini (Wahidah \& Ayem, 2015). Menurut Andari (2017), persistensi laba adalah laba yang dapat digunakan sebagai indikator laba masa depan. Dengan adanya konvergensi IFRS, diharapkan kualitas dari laba juga ikut meningkat yang antara lain dapat diindikasikan dari relevansi, prediktabilitas, persistensi, dan variabilitas laba.

Menurut penelitian yang dilakukan oleh S. B. Kristanto et al. (2014) diperoleh suatu kesimpulan bahwa setelah diterapkannya IFRS pada laporan keuangan konvergensi IFRS tidak berpengaruh positif pada kualitas laba. Penelitian tersebut hanya berfokus pada kualitas laba dengan indikator discretionary accruals, belum menganalisis aspek kualitas yang lain seperti relevansi, perstitensi. Variabilitas dan prediktabilitas. Penelitian lain pada umumnya juga masih membahas salah satu dari karakteristik laba, seperti penelitian yang dilakukan oleh Suprihatin and Tresnaningsih (2013); Cahyonowati and Ratmono (2012); A. B. Kristanto (2015) yang hanya meneliti tentang relevansi laba. Penelitian oleh Andari (2017); Shobriati and Siregar (2016); (Dewati \& Dewi, 2016) hanya meneliti kualitas laba dari aspek persistensinya. Sejauh pengetahuan penulis, penelitian mengenai prediktabilitas dan variabilitas masih belum banyak dilakukan. Hasil penelitian sebelumnya yang dilakukan oleh Suprihatin and Tresnaningsih (2013) menyatakan konvergensi IFRS tidak meningkatkan relevansi nilai laba , sedangkan dalam penelitian Cahyonowati and Ratmono (2012); A. B. Kristanto (2015) menyatakan konvergensi IFRS dapat meningkatkan relevansi nilai laba. Hasil penelitian sebelumnya yang dilakukan oleh (Dewati \& Dewi, 2016) menyatakan konvergensi IFRS meningkatkan persistensi, sedangkan dalam penelitian Andari (2017); Shobriati and Siregar (2016) menyatakan konvergensi IFRS tidak meningkatkan persitensi laba. Kualitas informasi laba perlu untuk dianalisis dengan lebih komprehensif pada berbagai aspek kualitas, agar dapat memberikan keyakinan kepada pengguna laporan keuangan dalam menggunakan informasi laporan keuangan, khususnya laba untuk mengambil keputusan. Kesenjangan penelitian inilah yang akan diisi oleh penelitian kali ini.

Penelitian ini bertujuan untuk: (1) Mengetahui apakah sesudah diterapkannya IFRS, persistensi laba bersih lebih tinggi daripada sebelum diterapkannya IFRS; (2) Mengetahui apakah sesudah diterapkannya IFRS, variabilitas laba bersih lebih rendah dibanding sebelum diterapkannya IFRS; (3) mengetahui apakah sesudah diterapkannya IFRS, laba bersih memiliki kemampuan prediksi lebih tinggi daripada sebelum diterapkannya IFRS; (4) Mengetahui apakah sesudah diterapkannya IFRS, relevasi laba bersih lebih tinggi daripada sebelum diterapkannya IFRS. Hasil penelitian ini diharapkan dapat bermanfaat bagi penyusun standar untuk mengevaluasi penerapan IFRS di Indonesia, sehingga dapat mengantisipasi untuk memastikan berkualitasnya informasi laporan keuangan. Bagi pengguna laporan keuangan secara umum, hasil penelitian ini dapat dipergunakan untuk mengevaluasi keyakinan dalam menggunakan informasi laporan keuangan untuk mengambil keputusan. Bagi perusahaan penelitian ini dapat digunakan sebagai pertimbangan penerapan IFRS dalam laporan keuangan. Serta bagi investor dapat digunakan sebagai keyakinan atas informasi akuntansi di dalam laporan keuangan sehingga investor dapat membuat keputusan secara tepat.

\section{Teori Sinyal}

Teori sinyal menitikberatkan pada pentingnya suatu informasi yang diberikan perusahaan akan suatu pertimbangan pihak eksternal perusahaan terhadap keputusan 
investasi (Syagata \& Daljono, 2014). Investor akan tertarik berinvestasi ketika perusahaan memberikan informasi secara lengkap, terbuka, akurat, relevan, dan tepat waktu pada laporan keuangannya. Laporan keuangan merupakan pertimbangan investor dalam berinvestasi karena laporan keuangan memiliki berbagai informasi perusahaan, selain itu investor dapat memprediksi risiko-risiko yang akan dihadapi dalam setiap pengambilan keputusan. Diharapkan informasi yang dikeluarkan perusahaan dapat menjadi sinyal-sinyal bagi investor untuk menanamkan modalnya.

\section{Konvergensi IFRS di Indonesia}

International Financial Reporting Standard (IFRS) adalah sebuah standar yang dipakai sebagai panduan dalam pelaporan keuangan dan digunakan secara global (Pacter, 2017). Sebelum penerapan IFRS, Indonesia menggunakan PSAK yang mengacu pada Generally Accepted Accounting Standard (GAAP) sebagai standar pembuatan laporan keuangan. IFRS dan GAAP mempunyai perbedaan yang cukup signifikan, dalam praktik penggunaannya GAAP mengatur praktik akuntansi secara rule based, sehingga standar akuntansi akan memberikan panduan yang detail. Sedangkan dalam IFRS, standar akuntansi dikembangkan secara principle based dimana standar hanya mengatur hal-hal yang bersifat prinsip dan tidak detail (Syagata \& Daljono, 2014). Dalam IFRS terdapat pengungkapan yang lebih luas dari standar sebelumnya sehingga informasi yang dihasilkan akan lebih luas dan dapat digunakan untuk mengambil keputusan dengan lebih tepat oleh para pemakai laporan keuangan. Harapan dari konvergensi IFRS ini adalah laporan keuangan yang disajikan lebih bermanfaat karena informasi yang disajikan lebih luas dan lengkap.

\section{Persistensi Laba}

Menurut Andari (2017), persistensi laba adalah sifat laba yang bisa dimanfaatkan dalam parameter laba periode masa yang akan datang (future earnings). Laba dapat terbentuk dari komponen yang bersifat permanen dan sementara (transitory). Pada umumnya, komponen permanen berasal dari aktivitas bisnis utama perusahaan yang diharapkan dapat tetap diperoleh di periode-periode mendatang. Adapun komponen transitori timbul bukan dari aktivitas bisnis utama perusahaan, dan diharapkan tidak akan berulang secara konsisten di periode-periode mendatang. Komponen transitory tersebut antara lain dapat berasal dari dampak suku bunga pasar, nilai tukar uang serta inflasi. Barth and Hutton (2004) berpendapat laba dapat disebut persisten apabila laba yang didapatkan bisa dipertahankan hingga masa yang akan datang. Laba yang secara mayoritas terbentuk dari komponen permanen, akan lebih persisten daripada laba yang mayoritas terbentuk dari komponen transitori. Laba yang persisten akan dapat dijadikan dasar estimasi laba di periode-periode mendatang.

\section{Variabilitas Laba}

Variabilitas mengacu pada sifat laba yang dapat berubah-ubah nilainya antar periode. Variabilitas laba dapat dikaitkan dengan smoothness laba (Hasanah \& Suzan, 2015). Variabilitas yang tinggi dapat mengindikasikan adanya risiko yang tinggi dalam perusahaan. Kondisi laba yang sangat bervariasi antar periode menandakan adanya perubahan hasil usaha yang ekstrim, sulit diprediksi sehingga berisiko tinggi dalam sudut pandang investasi. Laba yang smooth adalah laba dengan variabilitas yang rendah. Laba dengan dengan variabilitas rendah dikatakan lebih berkualitas dibanding dengan laba dengan variabilitas tinggi (Surifah, 2010). Laba dengan variabilitas rendah lebih memperbesar kepercayaan investor karena menunjukan bahwa operasi perusahaan stabil. 


\section{Kemampuan Laba untuk Memprediksi}

Nilai prediksi adalah nilai yang dapat digunakan sebagai informasi bagi para pengguna untuk memprediksi masa depan atas dasar kejadian masa sekarang maupun masa lalu (Wahidah \& Ayem, 2015). Laba terbentuk dari komponen arus kas bersih dan akrual. Menurut Surifah (2010), prediktabilitas laba juga harus menunjukkan kemampuan laba pada masa sekarang untuk memprediksi laba maupun arus kas operasi pada masa mendatang. Kemampuan laba untuk memprediksi berguna bagi setiap pengguna laporan keuangan untuk membuat keputusan. Risiko-risiko yang akan dihadapi perusahaan dapat dihindari dengan mempertimbangkan laba maupun arus kas bersih yang dapat didapatkan di masa-masa mendatang.

\section{Relevansi Nilai Laba}

Informasi akuntansi yang baik harus memiliki empat kriteria yaitu dapat dimengerti, reliable, dapat dibandingkan dan memiliki relevansi nilai (Mirza \& Holt, 2008). Informasi akuntansi yang memiliki relevansi nilai dapat mempengaruhi keputusan ekonomi dari pemakai (Naimah, 2014). Untuk mempengaruhi keputusan ekonomi dari pemakai, informasi akuntansi harus menggambarkan keadaan perusahaan. Informasi akuntansi yang dapat menggambarkan keadaan perusahaan dengan baik, mampu membantu pemakai informasi akuntansi dalam membuat keputusan. Informasi akuntansi yang relevan dapat dilihat melalui perubahan harga saham perusahaan.

Peran laba akuntansi dalam penentuan harga saham telah menjadi isu penting dalam penelitian-penelitian akuntansi (Naimah, 2014). Laba merupakan salah satu informasi akuntansi yang digunakan oleh pengguna laporan keuangan untuk membuat keputusan ekonomi. Maka dari itu laba sangat penting dalam laporan keuangan. Laba perlu memiliki relevansi nilai karena laba yang disajikan dalam laporan keuangan harus mampu menggambarkan dengan jelas kondisi perusahaan. Sehingga pengguna informasi akuntansi tidak salah dalam mengambil keputusan.

\section{Manfaat IFRS pada Persistensi Laba}

Nulla (2014) menyatakan bahwa konvergensi IFRS mampu meningkatkan persistensi laba dan arus kas. Persistensi laba mengalami peningkatan setelah implementasi IFRS dan membuat investor merespon baik informasi laba tersebut ditandai dengan naiknya harga saham perusahaan (Dewati \& Dewi, 2016). Persistensi laba yang meningkat dapat memberikan sinyal mengenai laba dan nilai perusahaan di masa yang akan datang, karena laba utamanya terbentuk dari elemen yang bersifat permanen. Persistensi laba yang meningkat membuat risiko ketidakpastian dimasa mendatang menurun, sehingga dapat menarik investor untuk melakukan investasi. Sebelum IFRS diimplementasikan tidak terdapat akun other comperhensive income sehingga dampakdampak non-bisnis seperti dampak nilai kurs, inflasi dan faktor pasar mempengaruhi laba bersih secara langsung karena hal tersebut dilaporkan dalam extraordinary item. Setelah adanya implementasi IFRS, dampak-dampak non-bisnis dilaporkan dalam other comperhensive income sehingga dampak tersebut tidak mempengaruhi laba bersih. Selain itu diharapkan laba bersih lebih menggambarkan keadaan bisnis utama perusahaan, sehingga menjadi lebih persisten setelah implementasi IFRS. Dari pembahasan diatas, maka dirumuskan hipotesis sebagai berikut.

H1: Sesudah diterapkannya IFRS, persistensi laba bersih lebih tinggi daripada sebelum diterapkannya IFRS 


\section{Manfaat IFRS pada Variabilitas Laba}

Investor akan mengambil keputusan berdasarkan risiko yang dihadapi dibandingkan dengan pengembalian yang diharapkan. Untuk tingkat pengembalian tertentu, investor sudah pasti memiliki harapan risiko investasi yang rendah. Tingkat risiko, antara lain ditunjukkan oleh ketidakpastian di masa mendatang. Variabilitas laba merupakan salah satu indikasi dari risiko yang dihadapi perusahaan. Perusahaan dengan laba yang sangat bervariasi antar periode memiliki risiko yang lebih tinggi untuk diinvestasikan, karena ketidakpastian laba di masa mendatang yang juga tinggi. Laba yang lebih berkulitas adalah laba yang mempunyai variabilitas relatif rendah atau laba yang smooth (S. B. Kristanto et al., 2014). Dengan diterapkannya IFRS variabilitas laba dalam perusahaan diharapkan dapat menurun. Dengan diimplementasikannya IFRS, komponen-komponen yang bukan berasal dari kinerja manajemen dieliminasi dari laba bersih ke akun laba komprehensif lain, sehingga laba bersih diharapkan lebih stabil antar periodenya. Dengan menurunnya variabilitas laba, mengindikasikan bahwa kinerja dari perusahaan tidak fluktuatif. Kinerja perusahaan yang stabil mampu menjadi dasar peramalan kinerja masa depan oleh investor. Menurut (Tanko, 2012) variabilitas laba bersih pada perusahaan menurun setelah diterapkannya IFRS. Selain itu, setelah implementasi IFRS tingkat manajemen laba menjadi lebih rendah (Kurniawati \& Rahmawati, 2014). Manajemen laba yang rendah diharapkan membuat laba perusahaan memiliki variabilitas yang rendah. Sehingga setelah implementasi IFRS diharapkan variabilitas laba perusahaan menjadi lebih rendah. Berdasarkan penjelasan tersebut, maka dirumuskan hipotesis sebagai berikut.

H2: Sesudah diterapkannya IFRS, variabilitas laba bersih lebih rendah dibanding sebelum diterapkannya IFRS

\section{Manfaat IFRS pada Kemampuan Laba dan arus kas untuk Memprediksi}

Uwuigbe, Uyoyoghene, Jafaru, Uwuigbe, and Jimoh (2017) menjelaskan bahwa kemampuan laba dalam memprediksi laba di masa mendatang dari Bank di Negeria yang terdaftar dalam Negerian Stock Exchange meningkat setelah pengadopsian IFRS. Menurut Nulla (2014), penerapan IFRS dalam laporan keuangan mampu meningkatkan kemampuan memprediksi laba dan arus kas. Kemampuan laba untuk memprediksi dapat digunakan untuk melihat nilai perusahaan di masa mendatang. Penerapan IFRS antara lain membuat laba bersih lebih mencerminkan kondisi kinerja dari bisnis, dengan mengeliminasi dampak non bisnis ke akun laba komprehensif lain. Hal ini akan membuat laba bersih lebih mampu dipergunakan untuk meramalkan baik laba maupun. Dengan adanya konvergensi IFRS diharapkan kemampuan laba dalam memprediksi laba dan arus kas operasi tahun depan dapat meningkat. Sehingga pengguna laporan keuangan mampu memprediksi keadaan perusahaan di masa mendatang dan membuat perencanaan dari informasi keuangan tersebut. Dari pembahasan tersebut maka dapat dijabarkan dalam hipotesis berikut ini.

H3a: Sesudah diterapkannya IFRS, laba bersih memiliki kemampuan prediksi terhadap laba bersih tahun depan lebih tinggi daripada sebelum diterapkannya IFRS

H3b: Sesudah diterapkannya IFRS, laba bersih memiliki kemampuan prediksi terhadap arus kas operasi tahun depan lebih tinggi daripada sebelum diterapkannya IFRS.

\section{Manfaat IFRS pada Relevansi Nilai Laba}

Kargin (2013) menjelaskan bahwa IFRS mampu meningkatkan relevansi nilai dari informasi akuntansi karena implementasi dari IFRS seperti menggunakan nilai wajar dalam laporan keuangan akan lebih mendekatkan besarnya nilai buku dan pasar. Akuntansi yang menggunakan nilai wajar dapat mengurangi kemungkinan untuk 
melakukan manajemen laba (A. B. Kristanto, 2015). Dan hal tersebut dapat dilihat dari penelitian Cai, Rahman, and Courtenay (2012) yang menyatakan bahwa setelah implementasi IFRS kemungkinan manajemen laba dalam sebuah perusahaan menurun. Dengan kelebihan tersebut diharapkan dapat meningkatkan relevansi nilai informasi, salah satunya adalah laba. Investor diharapkan dapat membuat keputusan yang lebih baik dari informasi yang dihasilkan oleh IFRS. Chebaane and Othman (2014) menyatakan bahwa pengadopsian IFRS mampu meningkatkan relevansi nilai laba dan nilai buku dari ekuitas per lembar saham. Jika relevansi nilai dari informasi akuntansi meningkat, maka informasi yang dihasilkan akan lebih berkualitas. Peningkatan relevansi nilai laba, akan mempermudah pengguna laporan keuangan untuk membuat keputusan ekonomi. Berdasarkan paparan tersebut maka dapat dijabarkan dalam hipotesis berikut.

H4: Sesudah diterapkannya IFRS, relevasi laba bersih lebih tinggi daripada sebelum diterapkannya IFRS

\section{METODE}

\section{Jenis Penelitian}

Penelitian ini menggunakan metode kuantitatif untuk meneliti dampak implementasi IFRS dalam kualitas informasi akuntansi dalam hal ini persitensi, variabilitas, kemampuan memprediksi, relevansi nilai pada perusahaan yang terdaftar di Bursa Efek Indonesia (BEI) selama tahun 2005-2015.

\section{Data dan Sumber Data}

Data yang digunakan dalam penelitian ini adalah data sekunder dalam bentuk time series dan cross section (data panel). Data yang digunakan adalah informasi keuangan berupa laba bersih, arus kas operasi, harga saham pada akhir tahun, jumlah lembar saham yang beredar dan nilai buku dari ekuitas pada perusahaan-perusahaan yang terdaftar di BEI selama tahun 2005-2016. Data diambil dari database Compustat untuk data laba bersih, arus kas operasi, dan nilai buku dari ekuitas dan Bursa Efek Indonesia untuk data harga saham dan jumlah saham yang beredar

\section{Populasi dan Sampel}

Populasi pada penelitian ini adalah laporan keuangan seluruh perusahaan di Bursa Efek Indonesia (BEI) dengan pembatasan pada perusahaan non-keuangan di Indonesia. Perusahaan keuangan dikecualikan dari penelitian ini, karena merupakan industri yang sangat ketat pengaturannya oleh pemerintah. Selanjutnya dilakukan penarikan sampel dengan menggunakan teknik purposive sampling yaitu menentukan sample dari populasi yang ada berdasarkan kriteria. Kriteria yang digunakan adalah: (1) perusahaan nonkeuangan yang terdaftar dalam BEI; (2) terdaftar berturut-turut selama tahun 2005-2016; (3) memiliki data penelitian yang lengkap.

\section{Definisi Operasional dan Pengukuran Variabel}

Persistensi nilai laba menggambarkan seberapa besar komponen laba tahun ini akan tetap bertahan sebagai komponen laba tahun mendatang. Penelitian ini mengukur persistensi laba dengan menggunakan model yang sama dengan penelitian Dechow and Schrand (2004) dalam Kabir and Laswad (2011), yaitu dengan menggunakan koefisien regresi $(\beta)$ dari persamaan 1. Jika $\beta$ semakin dekat dengan 1 , maka variabel tersebut semakin persisten. Persamaan model 1 dijalankan dua kali yaitu untuk periode sebelum dan sesudah konvergensi IFRS. Nilai $\beta$ dari persamaan 1 sebelum konvergensi IFRS dibandingkan dengan nilai $\beta$ dari persamaan 1 sesudah dilaksanakan konvergensi IFRS.

$N I_{t+1}=\alpha+\beta_{l} N I_{t}+\varepsilon_{t}$ 
$\mathrm{NI}_{\mathrm{t}} \quad$ : Net Income per share (Laba bersih per lembar saham) pada tahun $\mathrm{t}$.

$\mathrm{NI}_{\mathrm{t}+1} \quad$ : Net Income per share (Laba bersih per lembar saham) pada tahun $\mathrm{t}+1$

$\varepsilon_{t} \quad:$ Error

Variabilitas laba mengindikasikan fluktuasi laba dari tahun ke tahun. Seperti dalam penelitian Abimayu and Wirasendana (2015) pengukuran variabilitas menggunakan nilai coefficient of variance. Coefficient of variance laba bersih tiap-tiap perusahaan akan diperhitungkan untuk periode sebelum dan sesudah konvergensi IFRS. Coefficient of variance laba bersih didapatkan dari standar deviasi laba bersih dibagi rata-rata laba bersih. Selanjutnya, keseluruhan coefficient of variance laba akan dibandingkan antara sebelum dilaksanakan konvergensi IFRS dan sesudah dilaksanakan konvergensi IFRS

Prediktabilitas laba merupakan kemampuan laba untuk menjelaskan berapa besarnya laba atau arus kas operasi di periode mendatang. Untuk mengetahui kemampuan memprediksi laba dan arus kas, penelitian ini menggunakan model (2) dan (3). Peneliti menggunakan model yang sama dengan Dechow and Schrand (2004) dalam Kabir and Laswad (2011) untuk mengukur kemampuan laba dalam menjelaskan laba dan arus kas oprasional tahun depan. Koefisien determinasi $\left(\mathrm{R}^{2}\right)$ dari model 2 dan 3 merupakan proksi dari kemampuan laba bersih tahun ini untuk menjelaskan perubahan laba bersih atau arus kas tahun depan. Semakin tinggi nilai $\mathrm{R}^{2}$, maka laba dikatakan semakin memiliki kemampuan prediksi yang lebih baik. Persamaan 2 dan 3 akan diuji masing-masing dua kali, yaitu untuk periode sebelum dan sesudah konvergensi IFRS. Selanjutnya nilai $\mathrm{R}^{2}$ pada persamaan sebelum dan sesudah konvergensi akan dibandingkan untuk mencari tahu mana yang lebih besar nilainya.

$N I_{t+1} \quad=\alpha+\beta_{2} N I_{t}+$ $C F O_{t+1}=\alpha+\beta_{3} N I_{t}+\varepsilon_{1}$

$N_{t} \quad:$ Net Income per share (Laba bersih per lembar saham) pada tahun $\mathrm{t}$

$N I_{t+1} \quad$ : Net Income per share (Laba bersih per lembar saham) pada tahun $\mathrm{t}+1$

$\mathrm{CFO}_{t+1}$ : Cash Flow Operation per share (Arus Kas Operasi per lembar saham) pada tahun $\mathrm{t}+1$

$\varepsilon_{t} \quad:$ Error

Relevansi nilai informasi laba merepresentasikan kemampuan laba dalam menjelaskan perubahan harga saham. Informasi laba yang dapat menjelaskan perubahan harga saham menandakan bahwa informasi laba tersebut dipertimbangkan oleh investor dalam keputusan investasinya. Peneliti menggunakan persamaan yang sama dengan Ohlson (1995) dalam A. B. Kristanto (2015) untuk mengukur relevansi nilai dari laba bersih. Relevansi nilai laba bersih diukur dari koefisien determinasi $\left(\mathrm{R}^{2}\right)$ dari variabel independen (laba bersih, nilai buku ekuitas dan arus kas operasi) dalam memepengaruhi harga per lembar saham (A. B. Kristanto, 2015). Untuk melihat meningkatnya relevansi nilai informasi akuntansi sebelum dan sesudah konvergensi IFRS, $\mathrm{R}^{2}$ dari tiap variabel independen dalam persamaan 4 sebelum konvergensi IFRS dibandingkan dengan $\mathrm{R}^{2}$ dari tiap variabel independen dalam dari persamaan 4 setelah konvergensi IFRS.

$P_{t}=\alpha+\beta_{4} N I_{t}+\beta_{5} B V E_{t}+\beta_{6} C F O_{t}+{ }_{c}$

$P_{t} \quad$ : Harga per lembar saham pada akhir tahun $\mathrm{t}$

$N I_{t} \quad:$ Net Income per share (Laba bersih per lembar saham) pada tahun $\mathrm{t}$

$B V E_{t}$ : Book Value of Equity per share (Nilai buku ekuitas per lembar saham) pada tahun $\mathrm{t}$

$\mathrm{CFO}_{t}$ : Cash Flow from Operation per share (Arus Kas Operasi per lembar saham) pada tahun $\mathrm{t}$

$\varepsilon_{t} \quad:$ Error 


\section{Tahapan Analisis}

Metode analisis yang digunakan dalam penelitian ini adalah analisis kuantitatif deskriptif, dengan membandingkan indikator variabel antara sebelum dan sesudah konvergensi IFRS. Adapun dalam pengukuran variabel persistensi, kemampuan prediksi memanfaatkan regresi sederhana. Pengukuran variabel relevansi laba memanfaatkan regresi berganda. Setiap fungsi regresi yang dilakukan, dipastikan harus lolos uji asumsi klasik yaitu uji normalitas, autokorelasi, multikolinearitas serta heteroskedastisitas. Data dalam penelitian ini dibagi menjadi dua periode waktu yaitu sebelum (2005- 2009) dan sesudah konvergensi IFRS (2011-2015). Penerimaan atau penolakan hipotesis akan didasarkan pada teknik berikut ini:

Tabel 1. Panduan Penerimaan dan Penolakan Hipotesis

\begin{tabular}{|c|c|c|}
\hline Hipotesis & Penerimaan Hipotesis & Penolakan Hipotesis \\
\hline 1 & 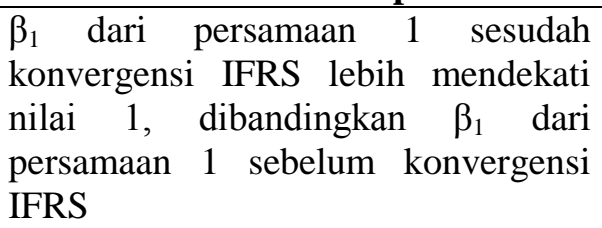 & $\begin{array}{l}\beta_{1} \text { dari persamaan } 1 \text { sesudah } \\
\text { konvergensi IFRS lebih menjauhi } \\
\text { nilai 1, dibandingkan } \beta_{1} \text { dari } \\
\text { persamaan } 1 \text { sebelum konvergensi } \\
\text { IFRS }\end{array}$ \\
\hline 2 & $\begin{array}{l}\text { Coefficient of variance laba } \\
\text { perusahaan pada periode sesudah } \\
\text { konvergensi IFRS lebih rendah } \\
\text { daripada coefficient of variance laba } \\
\text { perusahaan pada periode sebelum } \\
\text { konvergensi IFRS }\end{array}$ & $\begin{array}{l}\text { Coefficient of variance laba } \\
\text { perusahaan pada periode sesudah } \\
\text { konvergensi IFRS lebih tinggi } \\
\text { daripada coefficient of variance laba } \\
\text { perusahaan pada periode sebelum } \\
\text { konvergensi IFRS }\end{array}$ \\
\hline $\mathbf{3 a}$ & $\begin{array}{l}\mathrm{R}^{2} \text { dari persamaan } 2 \text { sesudah } \\
\text { konvergensi IFRS lebih besar, } \\
\text { dibandingkan } \mathrm{R}^{2} \text { dari persamaan } 2 \\
\text { sebelum konvergensi IFRS }\end{array}$ & $\begin{array}{l}\mathrm{R}^{2} \text { dari persamaan } 2 \text { sesudah } \\
\text { konvergensi IFRS lebih kecil, } \\
\text { dibandingkan } \mathrm{R}^{2} \text { dari persamaan } 2 \\
\text { sebelum konvergensi IFRS }\end{array}$ \\
\hline $3 \mathbf{b}$ & $\begin{array}{l}\mathrm{R}^{2} \text { dari persamaan } 3 \\
\text { konvergensi IFRS lebih besar, } \\
\text { dibandingkan } \mathrm{R}^{2} \text { dari persamaan } 3 \\
\text { sebelum konvergensi IFRS }\end{array}$ & $\begin{array}{l}\mathrm{R}^{2} \text { dari persamaan } 3 \text { sesudah } \\
\text { konvergensi IFRS lebih kecil, } \\
\text { dibandingkan } \mathrm{R}^{2} \text { dari persamaan } 3 \\
\text { sebelum konvergensi IFRS }\end{array}$ \\
\hline 4 & $\begin{array}{l}\mathrm{R}^{2} \text { dari persamaan } 4 \text { sesudah } \\
\text { konvergensi IFRS lebih besar, } \\
\text { dibandingkan } \mathrm{R}^{2} \text { dari persamaan } 4 \\
\text { sebelum konvergensi IFRS }\end{array}$ & $\begin{array}{l}\mathrm{R}^{2} \text { dari persamaan } 4 \text { sesudah } \\
\text { konvergensi IFRS lebih kecil, } \\
\text { dibandingkan } \mathrm{R}^{2} \text { dari persamaan } 4 \\
\text { sebelum konvergensi IFRS }\end{array}$ \\
\hline
\end{tabular}

\section{HASIL DAN PEMBAHASAN \\ Hasil Pengumpulan Data}

Penelitian ini bertujuan untuk mengetahui apakah karakteristik laba bersih semakin meningkat setelah konvergensi IFRS pada perusahaan yang terdaftar dalam BEI periode tahun 2005-2015. Berdasarkan kriteria yang ditentukan sebelumnya, diperoleh sampel penelitian sebesar 150 perusahaan (Tabel 2). 150 Perusahaan yang digunakan sebagai sampel penelitian terdiri dari 8 sektor.

Sektor pertanian terdapat 5 perusahaan yang menjadi sampel. Sektor pertambangan terdapat 11 perusahaan, sektor industri dasar dan kimia ada 30 perusahaan, sector aneka industri terdapat 23 perusahaan, sektor industri barang konsumsi ada 18 perusahaan, sektor properti, real estat, dan transportasi 13 perusahaan, serta sektor perdagangan, jasa dan investasi terdapat 44 perusahaan yang menjadi sampel (Tabel 3). 
Tabel.2 Hasil Pengambilan Sampel

\begin{tabular}{|c|c|c|c|c|c|c|c|c|c|c|c|c|}
\hline \multirow{2}{*}{ Kriteria Sampel } & \multicolumn{12}{|c|}{ Jumlah } \\
\hline & 2005 & 2006 & 2007 & 2008 & 2009 & 2010 & 2011 & 2012 & 2013 & 2014 & 2015 & 2016 \\
\hline $\begin{array}{l}\text { Perusahaan yang terdaftar } \\
\text { dalam BEI. }\end{array}$ & 325 & 360 & 408 & 442 & 462 & 492 & 508 & 518 & 528 & 530 & 530 & 521 \\
\hline $\begin{array}{l}\text { Perusahaan sektor keuangan } \\
\text { dan perusahaan yang tidak } \\
\text { terdaftar berturut-turut selama } \\
\text { tahun } 2005-2016 \text {. }\end{array}$ & (35) & (70) & (118) & $(152)$ & (172) & (202) & (218) & (228) & (238) & $(240)$ & (240) & (231) \\
\hline $\begin{array}{l}\text { Perusahaan non-keuangan yang } \\
\text { terdaftar berturut-turut tahun } \\
\text { 2005-2016 }\end{array}$ & \multicolumn{12}{|c|}{290} \\
\hline $\begin{array}{l}\text { Perusahaan non-keuangan yang } \\
\text { tidak memiliki kelengapan data } \\
\text { untuk penelitian. }\end{array}$ & \multicolumn{12}{|c|}{ (109) } \\
\hline $\begin{array}{l}\text { Perusahaan non-keuangan yang } \\
\text { memiliki data outlier }\end{array}$ & \multicolumn{12}{|c|}{ (31) } \\
\hline $\begin{array}{l}\text { Total Sampel Selama Periode } \\
\text { Penelitian 2005-2015 }\end{array}$ & \multicolumn{12}{|c|}{150} \\
\hline
\end{tabular}

Tabel. 3 Sektor Sampel Penelitian

\begin{tabular}{lc}
\hline \multicolumn{1}{c}{ Sektor } & Jumlah \\
\hline Pertanian & 5 \\
Pertambangan & 11 \\
Industri Dasar dan Kimia & 30 \\
Aneka Industri & 23 \\
Industri Barang Konsumsi & 18 \\
Properti, Real Estat dan Konstruksi Bangunan & 6 \\
Infrastruktur, Utilitas dan Transportasi & 13 \\
Keuangan & 0 \\
Perdagangan, Jasa dan Investasi & 44 \\
\hline Jumlah & 150 \\
\hline
\end{tabular}

\section{Statistik Deskriptif}

Statistik deskriptif adalah pengujian data statistik secara umum yang bertujuan untuk melihat distribusi data dari variabel yang digunakan dalam penelitian ini (Andreas, Ardeni, \& Nugroho, 2017). Dibawah ini adalah tabel statistik deskriptif dari masingmasing variabel penelitian (Tabel 4).

Tabel. 4 Statistik Deskriptif

\begin{tabular}{ccccccc}
\hline \multirow{2}{*}{ Variabel } & \multicolumn{3}{c}{ Sebelum IFRS (Rp) } & \multicolumn{3}{c}{ Setelah IFRS (Rp) } \\
\cline { 2 - 7 } & Minimum & Rata-rata & Maksimum & Minimum & Rata-rata & Maksimum \\
\hline $\mathbf{N I}_{\mathbf{t}}$ & $-860,23$ & 83,36 & 2184,13 & $-2788,46$ & 143,33 & 4393,14 \\
$\mathbf{N I}_{\mathbf{t + 1}}$ & $-860,23$ & 51,52 & 1479,83 & $-685,15$ & 82,01 & 1549,45 \\
$\mathbf{C F O}_{\mathbf{t}}$ & $-3200,69$ & 123,52 & 3275,69 & 13157,76 & 146,99 & 3275,96 \\
$\mathbf{C F O}_{\mathbf{t + 1}}$ & $-1437,84$ & 119 & 1699,36 & $-2317,37$ & 150,72 & 3275,96 \\
$\mathbf{B V E}_{\mathbf{t}}$ & $-1641,65$ & 706,92 & 9553,90 & 1957,89 & 1038,69 & 19753,73 \\
$\mathbf{P}_{\mathbf{t}}$ & 25,00 & 1787,42 & 96250,00 & 50,00 & 3833,70 & 189000 \\
\hline
\end{tabular}

Sumber : Data penelitian (2018)

$\mathrm{NI}_{t}$ adalah laba bersih per lembar saham pada tahun berjalan, sedangkan $\mathrm{NI}_{t+1}$ adalah laba bersih per lembar saham satu tahun setelah tahun berjalan. $\mathrm{CFO}_{\mathrm{t}}$ adalah arus 
kas operasi per lembar saham pada tahun berjalan, dan $\mathrm{CFO}_{\mathrm{t+1}}$ merupakan arus kas operasi per lembar saham satu tahun setelah tahun berjalan. $\mathrm{BVE}_{\mathrm{t}}$ adalah nilai buku per lembar saham pada tahun berjalan. $\mathrm{P}_{\mathrm{t}}$ adalah harga per lembar saham pada tahun berjalan.

Berdasarkan tabel 4 nilai rata-rata laba bersih per lembar saham pada tahun berjalan perusahaan yang terdaftar di BEI sebelum IFRS adalah Rp 83,36 dan setelah IFRS adalah Rp 143,33. Hasil ini menunjukan bahwa rata-rata nilai laba bersih per lembar saham meningkat setelah diterapkannya IFRS. Nilai rata-rata laba bersih per lembar saham satu tahun setelah tahun berjalan sebelum IFRS adalah Rp 51,52 dan setelah IFRS adalah Rp 82,01. Hasil ini menunjukan bahwa rata-rata nilai laba bersih per lembar saham satu tahun setelah tahun berjalan meningkat setelah diterapkannya IFRS. Rata-rata arus kas operasi per lembar saham perusahaan pada tahun berjalan sebelum IFRS Rp 123,52 dan setelah diterapkannya IFRS rata-rata arus kas operasi per lembar saham perusahaan meningkat menjadi Rp 146,99. Rata-rata arus kas operasi per lembar saham perusahaan satu tahun setelah tahun berjalan sebelum IFRS adalah Rp 119 dan setelah diterapkannya IFRS rata-rata perusahaan meningkat menjadi Rp 150,72. Rata-rata nilai buku per lembar saham pada tahun berjalan mengalami peningkatan, sebelum IFRS rata-ratanya adalah $\mathrm{Rp} 706,92$ sedangkan setelah diterapkan IFRS rata-rata nilai buku per lembar saham pada tahun berjalan menjadi Rp 1038,69. Rata-rata harga per lembar saham pada tahun berjalan sebelum IFRS yaitu Rp 1787,42 dan setelah IFRS menjadi Rp 3833,70. Hal ini menunjukan rata-rata harga per lembar saham pada tahun berjalan mengalami peningkatan setelah diterapkan IFRS.

\section{Uji Autokorelasi}

Uji autokorelasi digunakan untuk mengetahui apakah terjadi korelasi antar suatu periode dengan periode sebelumnya. Penelitian ini menggunakan pengujian DurbinWatson dengan menggunakan model cochrane orcutt untuk mengetahui apakah terdapat autokorelasi dalam data penelitian ini. Jika nilai Durbin-Watson (DW) lebih besar dari nilai du dan lebih kecil dari nilai 4-du maka tidak terdapat autokorelasi sehingga lolos dari uji autokorelasi (Tabel 5).

Tabel 5. Hasil Uji Autokorelasi

\begin{tabular}{ccccccc}
\hline \multicolumn{2}{l}{ Sebelum IFRS } & \multicolumn{1}{l}{ Du } & 4-du & 4-dl & DW & Kesimpulan \\
\hline Model & Dl & Du & 2,123 & 2,021 & Lolos \\
$\mathbf{1}$ & 1,877 & 1,883 & 2,117 & 2,123 & Lolos \\
$\mathbf{2}$ & 1,877 & 1,883 & 2,117 & 2,123 & 2,021 & Lolos \\
$\mathbf{3}$ & 1,877 & 1,883 & 2,117 & 2,123 & 2,004 & Lolos \\
\hline Setelah IFRS & 1,872 & 1,888 & 2,112 & 2,128 & 2,006 & \\
\hline Model & Dl & Du & 4-du & 4-dl & DW & Kesimpulan \\
\hline $\mathbf{1}$ & 1,877 & 1,883 & 2,117 & 2,123 & 2,028 & Lolos \\
$\mathbf{2}$ & 1,877 & 1,883 & 2,117 & 2,123 & 2,028 & Lolos \\
$\mathbf{3}$ & 1,877 & 1,883 & 2,117 & 2,123 & 2 & Lolos \\
$\mathbf{4}$ & 1,872 & 1,888 & 2,112 & 2,128 & 1,948 & Lolos \\
\hline
\end{tabular}

Sumber : Data penelitian (2018)

\section{Uji Normalitas}

Uji normalitas dilakukan untuk mengetahui apakah model residual dalam penelitian mempunyai distribusi normal atau tidak. Uji normalitas pada data penelitian ini menggunakan pendekatan grafik dengan menggunakan Normal P-P Plot of Regression Standardized Residual untuk melihat normalitas data. Jika persebaran data titik di sekitar 
sumbu diagonal dan mengikuti arah garis diagonal, maka model regresi memenuhi asumsi normalitas (Santoso, 2011). Normal P-P Plot of regression standardized Residual pada persamaan satu, dua, tiga dan empat sebelum dan setelah implementasi IFRS menunjukan persebaran titik data berada di sekitar sumbu diagonal dan mengikuti arah garis diagonal, sehingga seluruh persamaan dalam penelitian ini berdistribusi normal dan telah memenuhi asumsi normalitas.

\section{Multikolinearitas}

Multikolinearitas digunakan untuk mengetahui apakah terdapat korelasi antar variabel bebas dalam persamaan regresi linear berganda pada model 4. Multikolinearitas dapat dideteksi menggunakan Varians Inflating Factor (VIF). Jika nilai VIF kurang dari 10 menunjukan tidak terdapat korelasi antara variabel bebas dalam persamaan tersebut sehingga lolos uji multikolinearitas (Tabel 6).

Tabel 6 Hasil Uji Multikolinearitas Persamaan ke empat

\begin{tabular}{|c|c|c|}
\hline \multicolumn{3}{|l|}{ Sebelum IFRS } \\
\hline Variabel & VIF & Kesimpulan \\
\hline Nit & 1,737 & Lolos \\
\hline CFOt & 1,798 & Lolos \\
\hline BVEt & 1,728 & Lolos \\
\hline \multicolumn{3}{|l|}{ Setelah IFRS } \\
\hline Variabel & VIF & Kesimpulan \\
\hline Nit & 2,322 & Lolos \\
\hline CFOt & 1,568 & Lolos \\
\hline BVEt & 2,614 & Lolos \\
\hline
\end{tabular}

Sumber : Data penelitian (2018)

\section{Hasil Pengujian}

Pengujian hipotesis penelitian diuji dengan menggunakan analisis regresi sederhana untuk mengetahui persistensi dan kemampuan memprediksi laba bersih, dan analisis regresi berganda untuk mengetahui relevansi nilai laba bersih. Sedangkan untuk mengetahui variabilitas laba bersih, menggunakan analisis coefficient of variance dari laba bersih sebelum dan sesudah implementasi IFRS.

Tabel 7 Hasil Pengujian

\begin{tabular}{|c|c|c|c|c|c|c|c|c|c|c|}
\hline \multirow[t]{2}{*}{ Model } & \multirow{2}{*}{$\begin{array}{l}\text { Depe } \\
\text { nden }\end{array}$} & \multirow{2}{*}{$\begin{array}{c}\text { Indep } \\
\text { ende } \\
\text { nd }\end{array}$} & \multicolumn{4}{|c|}{ Sebelum IFRS } & \multicolumn{4}{|c|}{ Setelah IFRS } \\
\hline & & & $\begin{array}{l}\text { Coeffi } \\
\text { cient }\end{array}$ & $\mathbf{t}$ & Sig. & $\mathbf{R}^{2}$ & $\begin{array}{c}\text { Coeffi } \\
\text { cient }\end{array}$ & $\mathbf{T}$ & Sig. & $\mathbf{R}^{2}$ \\
\hline $1 \& 2$ & NIt+1 & NIt & 0,846 & 29,401 & 0,000 & 0,536 & 0,783 & 37,083 & 0,000 & 0,647 \\
\hline 3 & $\begin{array}{c}\text { CFOt } \\
+1\end{array}$ & NIt & 0,947 & 15,857 & 0,000 & 0,252 & 0,982 & 17,302 & 0,000 & 0,286 \\
\hline 4 & $\mathrm{Pt}$ & $\begin{array}{c}\text { NIt } \\
\text { BVEt } \\
\text { CFOt }\end{array}$ & $\begin{array}{l}3,521 \\
1,343 \\
0,268\end{array}$ & $\begin{array}{c}10,268 \\
6,788 \\
4,686\end{array}$ & $\begin{array}{l}0,000 \\
0,000 \\
0,000\end{array}$ & 0,450 & $\begin{array}{l}8,430 \\
1,605 \\
0,092\end{array}$ & $\begin{array}{c}22,046 \\
9,522 \\
1,549\end{array}$ & $\begin{array}{l}0,000 \\
0,000 \\
0,122\end{array}$ & 0,713 \\
\hline \multicolumn{2}{|c|}{ Variabel } & \multicolumn{3}{|c|}{ Mean } & \multicolumn{2}{|c|}{ Std. Deviation } & \multicolumn{4}{|c|}{ Coefficient of Variant } \\
\hline \multicolumn{2}{|c|}{$\begin{array}{l}\text { NIt Sebelum } \\
\text { IFRS }\end{array}$} & \multicolumn{3}{|c|}{47,6428} & \multicolumn{2}{|c|}{159,8641} & \multicolumn{4}{|c|}{3,356} \\
\hline \multicolumn{2}{|c|}{$\begin{array}{l}\text { NIt Setelah } \\
\text { IFRS }\end{array}$} & \multicolumn{2}{|c|}{85,4794} & & \multicolumn{2}{|c|}{221,6129} & \multicolumn{4}{|c|}{2,259} \\
\hline
\end{tabular}


Sumber : Data penelitian (2018)

Hasil regresi sederhana diatas menunjukan $\beta_{1}$ model 1 sebelum IFRS adalah 0,846 dengan nilai sig. sebesar 0,000 menunjukan bahwa NIt berpengaruh positif signifikan terhadap $\mathrm{NI}_{\mathrm{t}+1}$. Nilai $\beta_{1}$ model 1 sebelum IFRS memiliki arti nilai laba bersih tahun depan akan berubah sebesar 0,846 jika nilai laba bersih tahun ini berubah satu satuan. Nilai $\beta_{1}$ model 1 setelah IFRS adalah 0,783 menunjukan bahwa NIt berpengaruh positif signifikan terhadap $\mathrm{NI}_{\mathrm{t}+1}$. Nilai $\beta_{1}$ model 1 setelah IFRS adalah 0,783 dengan nilai sig. 0,000 yang memiliki arti nilai laba bersih tahun depan akan berubah sebesar 0,783 jika nilai laba bersih tahun ini berubah satu satuan. Dari hasil penelitian di atas menunjukan nilai $\beta_{1}$ model 1 sebelum IFRS lebih besar daripada nilai $\beta_{1}$ model 1 setelah IFRS.

Dari hasil regresi sederhana model 2 di atas diketahui nilai $\mathrm{R}^{2}$ dari model 2 sebelum IFRS adalah 0,536 dengan nilai signifikansi uji $\mathrm{F}$ pada output anova sebesar 0,000 , menunjukan bahwa kontribusi pengaruh NIt sebelum IFRS terhadap $\mathrm{NI}_{\mathrm{t}+1}$ sebesar 0,536 atau $53,6 \%$. Sedangkan sisanya sebesar $46,4 \%$ dipengaruhi oleh variabel lain diluar model regresi ini. Nilai $\mathrm{R}^{2}$ dari model 2 setelah IFRS adalah 0,647 dengan nilai signifikansi uji $\mathrm{F}$ pada output anova sebesar 0,000 , menunjukan bahwa kontribusi pengaruh NIt sebelum IFRS terhadap $\mathrm{NI}_{\mathrm{t}+1}$ sebesar 0,647 atau $64,7 \%$. Sedangkan sisanya sebesar 35,3\% dipengaruhi oleh variabel lain diluar model regresi ini. Dari hasil penelitian diatas nilai $\mathrm{R}^{2}$ model 2 setelah IFRS lebih besar dari nilai $\mathrm{R}^{2}$ sebelum IFRS, sehingga kontribusi pengaruh NIt terhadap $\mathrm{NI}_{t+1}$ setelah IFRS lebih besar dibandingkan dengan sebelum IFRS.

Dari hasil regresi sederhana model 3 di atas diketahui nilai $\mathrm{R}^{2}$ dari model 3 sebelum IFRS adalah 0,252 dengan nilai signifikansi uji $\mathrm{F}$ pada output anova sebesar 0,000 menunjukan bahwa kontribusi pengaruh $\mathrm{NI}_{\mathrm{t}}$ sebelum IFRS terhadap $\mathrm{CFO}_{\mathrm{t}+1}$ sebesar 0,252 atau $25,5 \%$. Sedangkan sisanya sebesar $74,5 \%$ dipengaruhi oleh variabel lain diluar model regresi ini. Nilai $\mathrm{R}^{2}$ dari model 3 setelah IFRS adalah 0,286 dengan nilai signifikansi uji $\mathrm{F}$ pada output anova sebesar 0,000, menunjukan bahwa kontribusi pengaruh $\mathrm{NI}_{t}$ sebelum IFRS terhadap $\mathrm{CFO}_{\mathrm{t}+1}$ sebesar 0,286 atau 28,6\%. Sedangkan sisanya sebesar 71,4 \% dipengaruhi oleh variabel lain diluar model regresi ini. Dari hasil penelitian diatas nilai $\mathrm{R}^{2}$ model 3 setelah IFRS lebih besar dari nilai $\mathrm{R}^{2}$ sebelum IFRS, sehingga kontribusi pengaruh $\mathrm{NI}_{\mathrm{t}}$ terhadap $\mathrm{CFO}_{\mathrm{t}}$ setelah IFRS lebih besar dibandingkan dengan sebelum IFRS.

Dari hasil regresi sederhana model $4 \mathrm{di}$ atas diketahui nilai $\mathrm{R}^{2}$ dari model 4 sebelum IFRS adalah 0,450 dengan nilai signifikansi uji $\mathrm{F}$ pada output anova sebesar 0,000, menunjukan bahwa kontribusi pengaruh $\mathrm{NI}_{\mathrm{t}}, \mathrm{CFO}_{\mathrm{t}}$ dan $\mathrm{BVE}_{\mathrm{t}}$ sebelum IFRS terhadap $\mathrm{P}_{\mathrm{t}}$ sebesar 0,450 atau $45 \%$. Sedangkan sisanya sebesar $55 \%$ dipengaruhi oleh variabel lain diluar model regresi ini. Nilai $\mathrm{R}^{2}$ dari model 4 setelah IFRS adalah 0,713 dengan nilai signifikansi uji $\mathrm{F}$ pada output anova sebesar 0,000 , menunjukan bahwa kontribusi pengaruh $\mathrm{NI}_{\mathrm{t}}, \mathrm{CFO}_{\mathrm{t}}$ dan $\mathrm{BVE}_{\mathrm{t}}$ sebelum IFRS terhadap $\mathrm{P}_{\mathrm{t}}$ sebesar 0,713 atau $71,3 \%$. Sedangkan sisanya sebesar $28,7 \%$ dipengaruhi oleh variabel lain diluar model regresi ini. Dari hasil penelitian diatas nilai $\mathrm{R}^{2}$ model 4 setelah IFRS lebih besar dari nilai $R^{2}$ sebelum IFRS, sehingga kontribusi pengaruh $\mathrm{NI}_{t}, \mathrm{CFO}_{t}$ dan $\mathrm{BVE}_{t}$ terhadap $\mathrm{CFO}_{t}$ setelah IFRS lebih besar dibandingkan dengan sebelum IFRS.

Nilai coefficient of variance laba bersih perusahaan sebelum IFRS adalah 3,356 yang memiliki arti tingkat variasi dari laba bersih sebesar 3,356. Nilai coefficient of variance laba bersih perusahaan setelah IFRS adalah 2,259 yang memiliki arti tingkat variasi dari laba bersih sebesar 2,259. Semakin besar nilai coefficient of variance laba bersih maka variabilitas dari laba bersih tersebut semakin tinggi. Dari hasil penelitian di atas menunjukan coefficient of variance laba bersih setelah IFRS lebih kecil dari pada 
nilai coefficient of variance laba bersih sebelum IFRS sehingga variabilitas laba bersih setelah IFRS lebih rendah daripada sebelum IFRS.

\section{HASIL DAN PEMBAHASAN Persistensi Laba}

Hipotesis 1 dalam penelitian ini adalah sesudah diterapkannya IFRS, persistensi laba bersih lebih tinggi daripada sebelum diterapkannya IFRS. Hipotesis tidak didukung oleh hasil penelitian. Dapat dilihat dari nilai $\beta_{1}$ dari persamaan 1 sesudah konvergensi IFRS lebih menjauhi nilai 1 , dibandingkan $\beta_{1}$ dari persamaan 1 sebelum konvergensi IFRS. Hal ini menunjukan adanya penurunan nilai persistensi laba setelah diterapkannya IFRS. Kemampuan laba bersih untuk menjadi parameter laba bersih di masa yang akan datang menurun setelah diterapkannya IFRS. Laba bersih perusahaan tebentuk dari komponen transitory dan permanen. Laba perusahaan yang memiliki komponen transitory lebih banyak dari pada komponen permanen akan menurunkan nilai persistensi laba. Komponen transitory dapat berasal dari dampak suku bunga pasar, nilai tukar uang serta inflasi. Hal ini memungkinkan presitensi laba perusahaan semakin menurun setelah IFRS. Salah satu penerapan IFRS adalah adanya principal based, dimana akuntan diberikan wewenang untuk menentukan suatu proses akuntansi sendiri dengan menggunakan personal judgment dari akuntan. Personal judgement menyebabkan penilaian akuntansi dilakukan berdasarkan pandangan subyektif. Hal ini dapat menimbulkan perbedaan persepsi pada setiap akuntan, seperti pengelompokan akun terkait penghasilan maupun beban dari kegiatan operasi setiap perusahaan atau akuntan tidak selaras. Penjelasan tersebut dapat menjadi indikasi penurunan persistensi laba setelah penerapan IFRS. Hasil penelitian ini sejalan dengan penelitian dari Andari (2017) yang menyatakan bahwa tidak terdapat peningkatan persistensi laba setelah diterapkannya IFRS dengan sebelum diterapkannya IFRS.

\section{Variabilitas Laba}

Hipotesis 2 dalam penelitian ini adalah sesudah diterapkannya IFRS, variabilitas laba bersih lebih rendah dibanding sebelum diterapkannya IFRS. Hipotesis ini didukung oleh hasil penelitian. Dapat dilihat dari coefficient of variance laba perusahaan pada periode sesudah konvergensi IFRS lebih rendah daripada coefficient of variance laba perusahaan pada periode sebelum konvergensi IFRS. Sehingga hipotesis kedua dalam penelitian ini diterima. Dari hasil penelitian diatas kualitas laba bersih perusahaan setelah diterapkannya IFRS meningkat, karena tingkat variabilitas setelah diterapkannya IFRS menurun. Dengan diterapkannya IFRS, komponen-komponen yang bukan berasal dari kinerja manajemen dihilangkan dari laba bersih ke akun laba komprehensif lain, sehingga laba yang dihasilkan perusahaan lebih stabil tiap tahunnya. Hal ini mengakibatkan variabilitas laba setelah IFRS lebih rendah dibandingkan sebelum IFRS diterapkan. Hasil penelitian ini sejalan dengan penelitian Penelitian ini sejalan dengan penelitian Tanko (2012) yang menyatakan bahwa variabilitas laba setelah IFRS lebih rendah daripada sebelum IFRS.

\section{Prediktabilitas Laba}

Hipotesis 3a dari penelitian ini adalah sesudah diterapkannya IFRS, laba bersih memiliki kemampuan prediksi terhadap laba bersih tahun depan lebih tinggi daripada sebelum diterapkannya IFRS. Dapat dilihat dari nilai $\mathrm{R}^{2}$ dari persamaan 2 sesudah konvergensi IFRS lebih besar, dibandingkan $\mathrm{R}^{2}$ dari persamaan 2 sebelum konvergensi IFRS. Dari hasil tersebut nilai $\mathrm{R}^{2}$ dari persamaan 2 sesudah konvergensi IFRS lebih besar, dibandingkan $\mathrm{R}^{2}$ dari persamaan 2 sebelum konvergensi IFRS, sehingga hipotesis 3a dari 
penelitian ini diterima. Konvergensi IFRS membuat laba bersih lebih menunjukan kondisi perusahaan, karena dengan diterapkannya IFRS dampak non-bisnis pada laba bersih perusahaan dieliminasi ke akun laba komprehensif lain. Hal ini akan membuat laba bersih lebih mampu dipergunakan untuk memprediksi baik laba bersih. Hasil penelitian ini sejalan dengan penelitian Uwuigbe et al. (2017) yang menjelaskan bahwa kemampuan laba dalam memprediksi laba di masa mendatang dari Bank di Negeria yang terdaftar dalam Negerian Stock Exchange meningkat setelah pengadopsian IFRS.

Hipotesis $3 \mathrm{~b}$ dari penelitian ini adalah sesudah diterapkannya IFRS, laba bersih memiliki kemampuan prediksi terhadap arus kas operasi tahun depan lebih tinggi daripada sebelum diterapkannya IFRS. Hipotesis ini didukung oleh hasil penelitian. Dari hasil tersebut nilai $\mathrm{R}^{2}$ dari persamaan 3 sesudah konvergensi IFRS lebih besar, dibandingkan $\mathrm{R}^{2}$ dari persamaan 3 sebelum konvergensi IFRS, sehingga hipotesis $3 \mathrm{~b}$ dari penelitian ini diterima. Hal ini terjadi karena penerapan IFRS antara lain membuat laba bersih lebih mencerminkan kondisi kinerja dari bisnis, dengan mengeliminasi dampak non bisnis ke akun laba komprehensif lain. Hal ini akan membuat laba bersih lebih mampu dipergunakan untuk meramalkan nilai arus kas operasi. Konsisten dengan hasil penelitian Nulla (2014), penerapan IFRS dalam laporan keuangan mampu meningkatkan kemampuan memprediksi laba dan arus kas operasi.

\section{Relevansi Nilai}

Hipotesis 4 dari penelitian ini adalah sesudah diterapkannya IFRS, relevasi laba bersih lebih tinggi daripada sebelum diterapkannya IFRS. Hipotesis ini didukung oleh hasil penelitian. Dari hasil tersebut nilai $\mathrm{R}^{2}$ dari persamaan 4 sesudah konvergensi IFRS lebih besar, dibandingkan $\mathrm{R}^{2}$ dari persamaan 4 sebelum konvergensi IFRS, sehingga hipotesis 4 dari penelitian ini diterima. Dan hal tersebut dapat dilihat dari penelitian Cai et al. (2012) yang menyatakan bahwa setelah implementasi IFRS kemungkinan manajemen laba dalam sebuah perusahaan menurun. Dengan kelebihan tersebut dapat meningkatkan relevansi nilai informasi, salah satunya adalah laba. Sejalan dengan hasil penelitian Chebaane and Othman (2014) yang menyatakan bahwa pengadopsian IFRS mampu meningkatkan relevansi nilai laba perusahaan.

\section{KESIMPULAN}

Dari pembahasan diatas dapat ditarik kesimpulan bahwa setelah diterapkan IFRS persistensi laba bersih lebih rendah; variabilitas laba bersih perusahaan lebih rendah; kemampuan laba bersih dalam memprediksi laba bersih dan arus kas operasi lebih tinggi; dan relevansi nilai laba bersih perusahaan lebih tinggi dibandingkan dengan sebelum diterapkannya IFRS.

Secara praktis, hasil penelitian ini menunjukan adanya peningkatan karakteristik laba yaitu meningkatnya kemampuan prediksi dan relevansi nilai laba bersih, serta menurunnya variabilitas laba bersih. Hasil penelitian ini dapat meyakinkan pengguna laporan keuangan dalam menggunakan informasi akuntansi pada laporan keuangan yang sudah menerapkan IFRS untuk pengambilan keputusan bisnis yang lebih baik. Bagi IAI sebagai penyusun standar, hasil penelitian ini dapat dijadikan salah satu masukan bagi evaluasi manfaat pengimplementasian IFRS di Indonesia.

Dalam ranah akademik, penelitian ini konsisten dengan penelitian Andari (2017); Shobriati and Siregar (2016) yang menyatakan bahwa setelah diterapkannya IFRS persistensi laba bersih lebih rendah dibandingkan sebelum ditetapkannya IFRS, tetapi tidak konsisten dengan penelitian (Dewati \& Dewi, 2016) yang menyatakan persistensi laba setelah IFRS lebih tinggi. Penelitian ini konsisten dengan penelitian Cahyonowati and Ratmono (2012); A. B. Kristanto (2015) yang menyatakan bahwa setelah 
diterapkannya IFRS relevansi laba bersih lebih tinggi dibandingkan sebelum ditetapkannya IFRS, tetapi tidak konsisten dengan penelitian Suprihatin and Tresnaningsih (2013) yang menyatakan konvergensi IFRS tidak berpengaruh pada relevansi laba.

Dalam penelitian ini terdapat beberapa keterbatasan yang dapat dipertimbangkan untuk dalam agenda penelitian selanjutnya: (1) Laba bersih terbentuk dari berbagai macam komponen, seperti penghasilan dan beban oprasional. Penelitian ini belum meneliti secara detail komponen dalam laba bersih apa yang menyebabkan laba bersih relevan, memiliki kemampuan prediksi, persisten, dan memiliki variabilitas yang rendah. Penelitian selanjutnya diharapkan dapat memperdalam analisis untuk mengetahui komponen-komponen yang berperan dalam membentuk relevansi nilai, keampuan prediksi, persisten dan variabilitas laba bersih. (2) Penelitian ini juga belum melihat relevansi informasi akuntansi, jika dikaitkan dengan tingkat likuiditas saham serta earning response corfficient. Likuiditas saham merupakan salah satu faktor yang menarik investor dalam menanamkan modalnya. Investor akan lebih tertarik pada saham yang likuiditasnya tinggi. Earning response corfficient mengindikasikan seberapa besar respon pasar terhadap laba. Penelitian selanjutnya diharapkan dapat menganalisis relevansi laba berdasarkan likuiditas saham dan earning response corfficient.

\section{DAFTAR PUSTAKA}

Abimayu, M. K. A., \& Wirasendana, W. P. (2015). Pengaruh Ukuran Perusahaan, Variabiitas Pendapatan dan Operating Leverage pada Struktur Modal Industri Perbankan. E-Jurnal Akuntansi Universitas Udayana, 11(3), 848-862.

Andari, A. T. (2017). Analisis Perbedaan Kualitas Akrual dan Persistensi Laba Sebelum dan Sesudah Konvergensi IFRS. Jurnal Kajian Akuntansi, 1(2), 133-147.

Andreas, H. H., Ardeni, A., \& Nugroho, P. I. (2017). Konservatisme Akuntansi di Indonesia. Jurnal Ekonomi dan Bisnis, 20(1).

Barth, M. E., \& Hutton, A. P. (2004). Analyst Earnings Forecast Revisions and the Pricing of Accruals. Review of Accounting Studies.

Cahyonowati, N., \& Ratmono, D. (2012). Adopsi IFRS dan Relevansi Nilai Informasi Akuntansi. Jurnal Akuntansi dan Keuangan, 14(2), 105-115.

Cai, L., Rahman, A., \& Courtenay, S. (2012). Is it IFRS Adoption or Convergence to IFRS that Matters? Paper presented at the TIJA Symposium, New Zealand.

Chebaane, S., \& Othman, H. B. (2014). The Impact of IFRS Adoption on Value Relevance of Earnings and Book Value of Equity: The Case of Emerging Markets in African and Asian Regions. Procedia - Social and Behavioral Sciences, 145.

Dechow, P. M., \& Schrand, C. (2004). Earnings Quality. Research Foundation for CFA Institute.

Dewati, D. P., \& Dewi, N. H. U. (2016). Analysis Differences og Earnings Quaity Before and After Adoption of IFRS on The Food and Baberages Companies Listed in Indonesia Stock Exchange (Strata satu Skripsi), Sekolah Tinggi Ilmu Ekonomi PERBANAS, Surabaya. 
Hasanah, U., \& Suzan, L. (2015). Analisis Komparasi Kualitas Laba Sebelum dan Sesudah Audit Adjustment. e-Proceeding of Management, 2(1), 233.

Kabir, M. H., \& Laswad, F. (2011). Properties of Net Income and Total Comperhensive Income: New Zealand Evidance. Accounting Research Journal, 24(3), 268-289.

Kargin, S. (2013). The Impact of IFRS on The Value Relevance of Accounting Information: Evidence from Turkish Firms. International Journal of Economics and Finance.

Kristanto, A. B. (2015). Does IFRS Convergence Promote the Value Relevance of Accounting Information? Jurnal Ekonomi dan Bisnis, 18(2), 19-40.

Kristanto, S. B., Tarigan, K., \& Tarigan, M. U. (2014). Dampak Konvergensi IFRS Terhadap Kualitas Laba dengan Ukuran KAP sebagai Variabel Moderasi. Paper presented at the 3rd Economic and Business Reasearch Festival, Salatiga.

Kurniawati, L., \& Rahmawati. (2014). Pengaruh Adopsi IFRS terhadap Manajemen Laba pada Perusahaan Manufaktur yang Terdaftar di Bursa Efek Indonesia. Jurnal Akuntansi dan Auditing, 11(1), 120-133.

Mirza, A. A., \& Holt, G. J. (2008). Wiley IFRS: Practical Implementation Guide and Workbook. Canada: John Wiley \& Sons .Inc.

Naimah, Z. (2014). Relevansi Nilai Informasi Akuntansi: Suatu Kajian Teoritis. Jurnal Buletin Studi Ekonomi, 19(1).

Nulla, Y. M. (2014). Does IFRS Adoption Influence Quality of Reporting?: An Empirical Evidence from Large Canadian Banks. International Journal of Accounting and Taxation, 2(2), 85-109.

Nurharyanto. (2010). International Financial Reporting Standards (IFRS) : Konvergensi dan Kendala Implementasi di Indonesia. Paper presented at the PUSDIKLATWAS BPKP, Ciawi.

Ohlson, J. A. (1995). Earnings, Book Value and Devidends in Equity Valuation. Contemporary Accounting Research, 11(2).

Pacter, P. (2017). Pocket Guide to IFRS Standards: The Global Financial Reporting Languange

Paradiba, L., \& Nainggolan, K. (2015). Pengaruh Laba Bersih Operasi Terhadap Harga Saham Pada Perusahaan Food and Beverage yang Terdaftar di BEI. Jurnal Riset Akuntansi da Bisnis, 15(1).

Santoso, S. (2011). Mastering SPSS. Jakarta: Kompas Gramedia.

Sari, E. L. (2015). Pengaruh Pemberian Kompensasi terhadap Produktivitas Kerja Karyawan pada PT Ryan Jaya Persada. Jurnal Ilmu dan Riset Manajemn, 4(12).

Shobriati, I., \& Siregar, S. V. N. P. (2016). Pengaruh Tingkat Adopsi IFRS dan Proteksi Investor terhadap Persistensi Laba: Analisis Lintas Negara Emerging Markets. Jurnal Manajemen Teknologi, 15(3), 324-344. doi:10.12695/jmt.2016.15.3.7 
Volume 4 No. 1., Mei 2018

Suprihatin, S., \& Tresnaningsih, E. (2013). Dampak Konvergensi International Financial Reporting Standards terhadap Nilai Relevan Informasi Akuntansi. Jurnal Akuntansi dan Keuangan Indonesia, 10(2), 171-183.

Surifah. (2010). Kualitas Laba dan Pengukurannya. Jurnal Ekonomi, Manajemen dan Akuntansi, 8(2).

Suyatmini, \& Sheilla, A. (2014). Kajian Tentang Konvergensi IFRS di Indonesia. Jurnal Pendidikan Ilmu Sosial, 24(1), 79-86.

Syagata, G. S., \& Daljono. (2014). Analisis Komparasi Relevansi Nilai Informasi Akuntansi Sebelum dan Sesudah Konvergensi IFRS di Indonesia. Diponegoro Journal of Accounting, 3(3).

Tanko, M. (2012). The Effect of International Financial Reporting Standards (IFRS) Adoption on the Performance of Firms in Nigeria. Journal of Administration and Economic Sciences, 5(2), 133-157.

Uwuigbe, U., Uyoyoghene, A. L., Jafaru, J., Uwuigbe, O. R., \& Jimoh, R. (2017). IFRS Adoption and Earnings Predictability: Evidence from Listed Banks in Nigeria". Banks and Bank Systems, 12(1).

Wahidah, U., \& Ayem, S. (2015). Pengaruh Pengadopsian International Fiancial Reporting Standards (IFRS) terhadap Kualitas Informasi Akuntansi pada perusahaan yang Terdaftar di Bursa Efek Indonesia. Paper presented at the Syariah Paper Accounting FEB UMS. 